International Journal of Advanced Studies in Humanities and Social Science (IJASHSS) Available online at http://www.ijashss.com

Volume 8, Issue 1 (2019) pp. 28-44

Original Article

\title{
Evaluation the Effect of Construction of Ecotourism - Entertainment Facility in Hormoz Island with the Vernacular Architecture Approach
}

\section{HasanAli Pourmand ${ }^{1}$, HamidReza Ameri Siahouei², Mohammadreza Yeganeh $^{3}$}

\author{
${ }^{1}$ Assistant Professor, University of Tarbiat Modarres, Department of Architectal \\ Engineering, Tehran, Iran \\ ${ }^{2}$ Assistant Professor, Payam-e-Nour University, Hormozgan Branch, Department of \\ Architect Engineering, Bandar-e-Abbas, Iran \\ ${ }^{3}$ M. Sc Student, Islamic Azad University, Hormozgan Branch, Department of Architectal \\ Engineering, Bandar-e-Abbas, Iran
}

Received: 24 October 2018, Revised: 05 December 2018, Accepted: 20 December 2018

\begin{abstract}
Tourism as one of the most important factors areas 'development is an exchange an balanced activity which lead to social and economic development in regional level and justly distribution of income and also, it contributing the employment and today, its related activities included the largest industrial sector and world exports.Ecotourism is a type of tourism which is basis on special advantages of natural history in one region. Ecotourism has comparative advantage than in other branches of ecotourism in Iran. Hormoz Island is one of the vulnerable areas in this field. Tourism development of Hormoz island, providing new employment opportunities for local people by is an instrument which will be give an again life to this area and causing development of this area. Other hand, tourism development of the island of Hormoz without the proper planning will result in irreparable harm and loss. Therefore, according to the capability and environmental characteristics of region should be use specific strategic and approaches to utilize planning for tourism development of the island of Hormoz. The aim of this paper is consideration of the impacts of recreational tourist center on the island of Hormoz in southern Iran with native architecture to understand the importance of building amenities and easy commute to attract tourists and make them familiar with the beliefs and customs of a place to study and culture of local area with the least damage to the environment. Therefore, after considering the concepts of ecotourism, indigenous architecture oriented in the study area and potential factors of the island of Hormoz to assess how the island has become a tourist area with the least damage to the environment. Finally, the conditions and results of SWOT analysis will be described.
\end{abstract}

Keywords: Ecotourism, SWOT Approach, Vernacular Architecture, Hormoz Island. 


\section{Introduction}

The long journey trying to identify the unknown and writing travelogues by people such as Marco Polo, Magellan, Nasir, Benjamin Tvdlay all reminiscent of tourism in ages past, but today, tourism has a different concept of tourism and with different purposes such as recreation, tourism, pilgrimage and leisure. Tourism activities are based mainly resources and attractions, on the natural environment and human environment, which making available to the tourists. Obviously, recreational and recreational use of the environment, facilities and needs the right conditions and protection of these resources is required. This is determined by assessing their environmental capacities and capacity demands of Hospitality and Tourism estimated to be realized. Ecotourism ("echo" in Cognitive Ecology) is a kind of tourism which mainly based on the natural history of a region. This concept was raised by eco development of member 'countries and sustainable literature in the 1970s and 1980s and significantly and controversies were discussed. These benefits represent a suitable alternative to mass tourism model that social and environmental conditions of destinations around the world have been transformed; ecotourism is kind of activities that if properly done, leading to protection of the environment against harm such as destruction of natural landscapes, threatening wildlife, causing all kinds of pollution and the breakdown of local communities.

This paper will pay to examine the recreational - ecotourism center in Hormoz Island resorts in the context of ecosystem -oriented approach. Hence, first of all, necessity for establishment of urban ecology and urban ecology oriented and cognition -oriented concepts, features cultural and behavioral patterns in the content analysis method with consideration of existing patterns as a case study based on physical criteria, practical and meaningful will be offer. The main finding of this study suggests that the world is thinking about sustainable development with indigenous designing of urban spaces in framework, function and meaning which could be anyone who sought to replace the logic of the values of traditional contemporary or indigenous the principles of sustainable urban development and urban. For a continued presence and secure invite to their selves and it provides the indigenous identity in the new urban development, rearing young, and most of all a sense of selfactualization which causes to promote of quality of human environment and maintain the viability of the ultimate goal of the principles of urban design and sustainable urban development.

\section{Methodology}

This study examines existing potentials in Hormoz Island and the evaluation of how the island has become a tourist area that could be convert to a tourism area without any unharmed environmentally. This article is based on a qualitative discussion of descriptive - analytic study this paper analyzes the question of experts and field data collected using qualitative descriptive approach to model practical example we will eventually. The SWOT analysis was used to analyze the conditions of the island of Hormoz. 


\section{Definition of Ecotourism}

Tourism has always been a factor for economic development. This industry could lead to economic and social changes. The tourism will affect national economy through impact on national income, employment, price changes and trade balance (Ranjbarian and Zahedi, 1379).

In book of tourism' anthropology (Smith) has been considered various affect in this regard.

Some types of socio-economic impacts are natural changes and including pressures of any kind of economic, even if natives and tourists have the same cultural background.

Other effects of social - economic difference between natives and tourists which may have areas of same social economic which differences in relative levels of social development political economy natives and tourists has been identified as an important factor.

The third type of effect resulting from significantly cultural differences between natives and tourists. These differences

may be related to main value and legal systems, religious beliefs, customs, customs, lifestyle, behavior patterns, clothing, time division, attitudes towards foreigners and another factors.

\section{The View of Some Researchers Regarding the Definition of Ecotourism}

Trip to nature in a way that also protects the ecosystem, as well as respect to their local communities. In addition to the definition of natural resources, according to the local values and the need to establish a balance between natural resources, tourism, local community, and tourists are taken into consideration (Tisdell), 2000).

Hector Sbavs - Lazkvryn of the first people in the 1980s has provided a definition for ecotourism, he said the ecotourism travel almost undisturbed natural areas with the aim of learning and the admiration of natural scenery wildlife and the, past and present cultural expression and indigenous people (Ceballos and Lascurain, 1993).

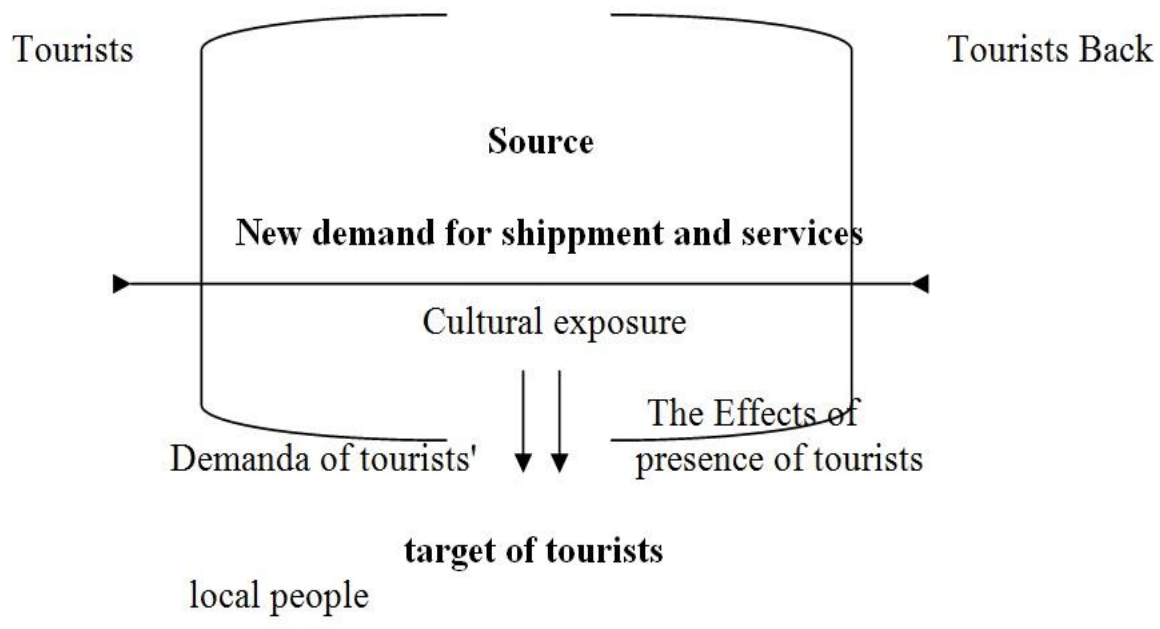

source: Journal of tourism studies, Mehdi Kazemi, r..r.

Figure 1. Effects resulting from the Significant Cultural differences between Natives and Tourists 
Advisory Council on the Canada Environment knows ecotourism same as a travel experience to nature that help to protect ecosystems and also, it maintain the host community.

International Union for Conservation of Nature is defined ecotourism: Ecotourism is responsible travel to relatively pristine natural areas to enjoy nature in a way that few adverse effects on the environment and economic participation and social - of the population bring.

Four characteristics of ecotourism as follows:

Dependent on nature.

In terms of ecological should be sustainable and the other hand, it has at the least damage and have adverse effects for the environment. Providing training and visited the region, its main ingredient is viewed.

Host and local communities participate in it.

\section{Three-Fold Aspect of Ecotourism}

Ecotourism should come from three aspects of science, society and economy and have focused on the following main topics:

Sientifical: 1. Good understanding of the natural capacity of ecosystems to ensure better protection of severely consider, rebuild or Bhynhpaydar produce them. 2. Protecting natural heritage, cultural and religious tourism in the area. 3. Prized legacy of information, culture and education in local communities as well as permanent damage to the tourists.

Social: 1. Recognization and respect to the important role of people of local communities and participation of them in decision- making, planning, and implementation of projects 2 . Respecting the basic needs of people and communities dependent on forests, forest areas and resources. 3. Positive exchange between tourists and the host local community people and promote a maintention culture of natural heritage guest tourists and host. 4. Promote quality of life and consciousness of the people and local communities.

Economical: 1. Income for the people, local communities and distribution of fair incomes. 2. Proportion of revenue for the management of heritage protection. 3. Ecotourism economical for its organizers, and also, careful attention to preserving and protecting the positive outcomes of the projects.

\section{Types of Ecotourism}

There is various classification of ecotourism. Here, it pointed some basic classification becomes more and more popular ecotourism.

\section{Hard and Soft Ecotourism}

Dares and Lyrmn and of the first people who paid attention to the hardness of ecotourism. The degree of ease or difficulty of ecotourism reflected in the graph.

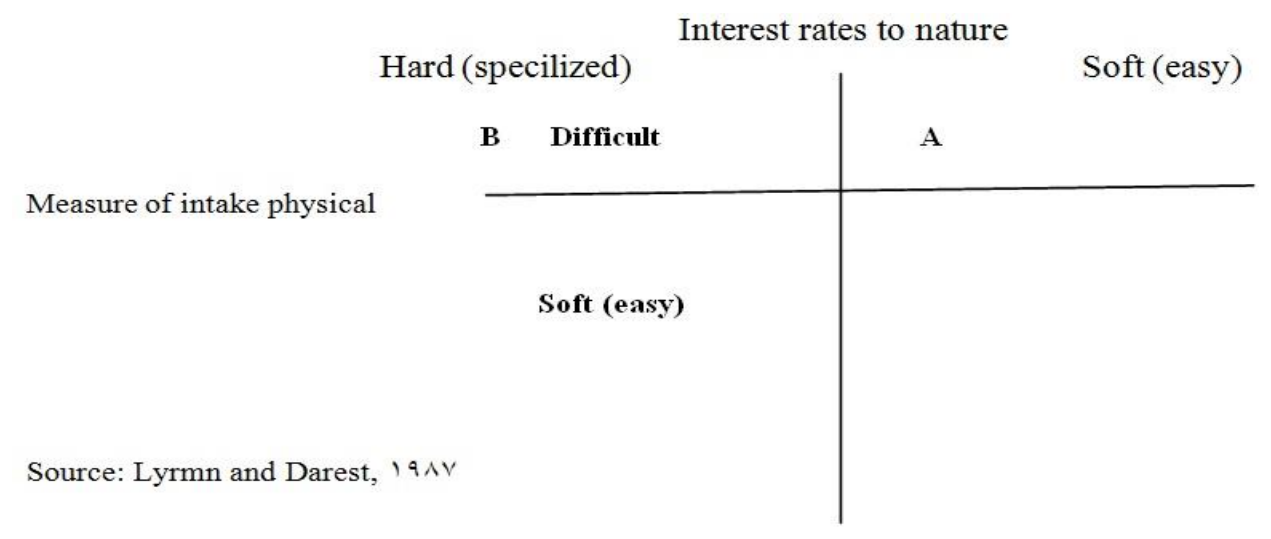

Figure 2. Chart of Hard and Soft Ecotourism Dimension 
Lyrmn and Darest believe that some of the touristy willing to endure hardship and austerity for more direct experience of nature, and so they take to $\mathrm{B}$ and some has no considerable effort in this area and take to $\mathrm{A}$. In ecotourism, soft or easy, is considered more facilities for ecotourism and in ecotourism, hard or specialized, is established more and more direct interaction between ecotourism and the natural environment and the minimum support facilities, are used. The rate of utilization of facilities is less support, ecotourism would be harder.

Table of ecotourism venture, soft or hard, is effective. Keristians has shown the relationship between hard and soft ecotourism for degree of risk by charts in 1990.

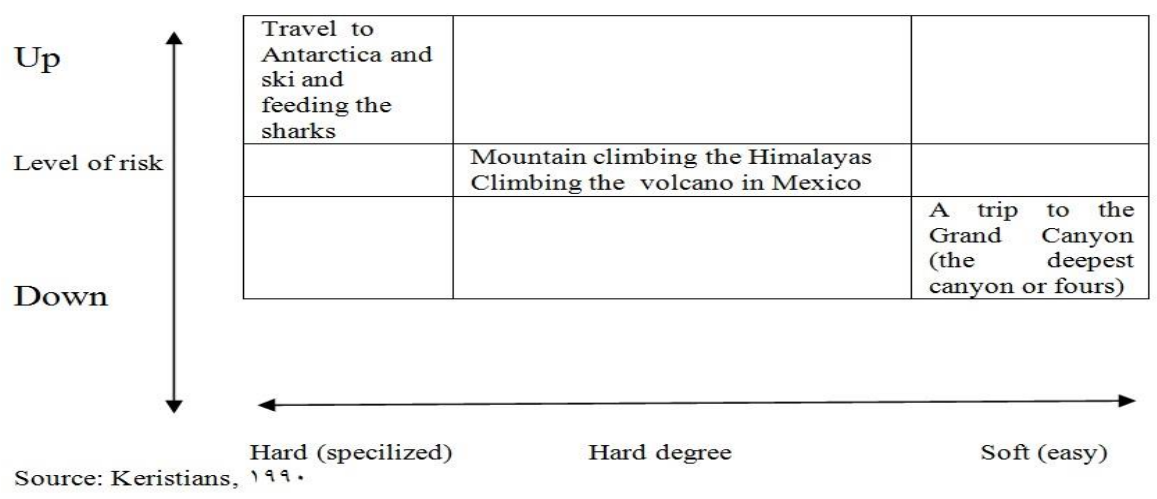

Figure 3. Risk Levels Chart at Planned Tours

As you can see in the above chart tourists who select activity of soft and easy has low risk and less adventurous and tourists who select activity of difficult and adventurous activities are more tolerant and accept possible risks. However, those interested in difficult ecotourism they enjoy challenge with nature and are interested to the experience.

The following tables have been shown characterization and groups that are interested in this range.

\section{Ecotourism, Soft (Easy) and Hard Ecotourism (PRO)}

Little resposibility

Continuum of Ecotourism



Source: Avarmez, 1990

Figure 4. Continuum Chart of Responsibility and Ecotourism
In other classification, ecotourismhas been divided to active and passive.

\section{Passive and Active Ecotourism}

In active ecotourism is emphasized on activities and measures which causes changes in tourists' behavior and help the environment. In passive ecotourism, only should consider the tourist satisfaction and his comfortable. Ouramez has been related the degree of active or passive ecotourism to the degree of human responsibility. 
Table 1. Comparison of Hard and Soft ecotourism

\begin{tabular}{|c|c|}
\hline Soft ecotourism (Easy) & Hard Ecotourism (Specilized) \\
\hline Large groups & Small groups \\
\hline Diverse travel experience & Certain travel to nature \\
\hline Accidental exposure to nature & Prolonged and long-term exposure to nature \\
\hline Moderate interest and commitment & Interset and serve commitment \\
\hline $\begin{array}{l}\text { Visit the reformed district's and more } \\
\text { favorable areas }\end{array}$ & Visit the virigin area \\
\hline $\begin{array}{l}\text { Taking advantage of the many benefits of } \\
\text { tourism services }\end{array}$ & $\begin{array}{l}\text { Taking advantage of the limit benefits fro, } \\
\text { tourism }\end{array}$ \\
\hline
\end{tabular}

\section{Ecotourism Right and Wrong}

Ecotourism can be classified in terms of the impact on the natural environment. This classification relates to ethics. Some authors have considered this subject and they see the light, tourism by doing "the right thing". Refers to the right of the Peter Drucker, management expert who is a distinction between the right and do the right thing ( Ikaf, 2001) on ecotourism, the point is that you should determine what is true and then it should be planned to do it right. In ecotourism, things which is exactly what the integrity, stability and beauty of the biotic not put a dent otherwise, the work will be wrong. Avramez deemed a positive and responsible ecotourism, which the natural environment helps improve and activities that reduce the quality of the natural environment and exploitation noresponsibility and realistic to consider. These are activities between these two poles with least effect on the natural environment. Considering what happened, ecotourism is true that in the continuum forms the hub of ecotourism goes active.

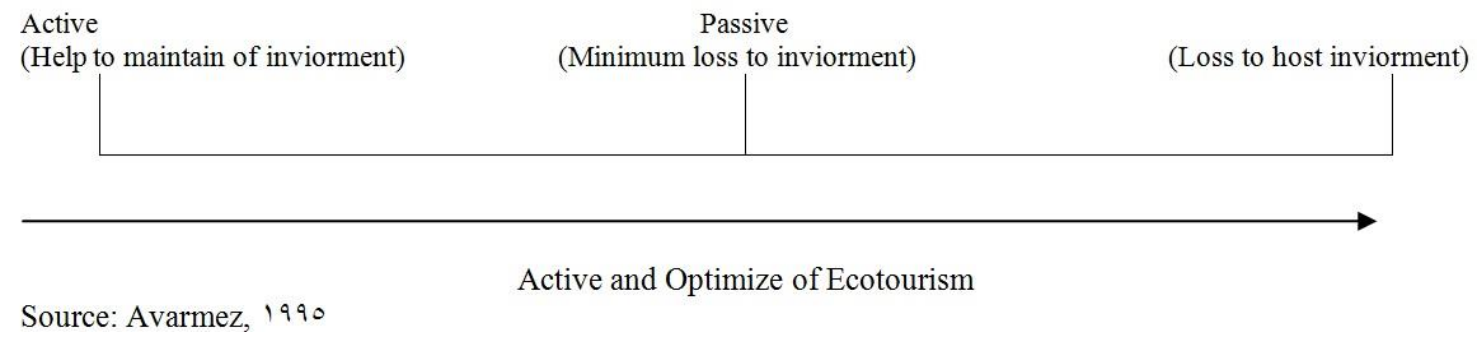

Figure 5. Continuum diagram of ecotourism types

\section{Principles of Ecotourism}

Minimize the negative effects of environmental, cultural, destined which causes to damage.

Educate visitors about the importance of protecting

Emphasize the importance of corporate responsibility and partnerships with local authorities and people to meet local needs and creating benefits for Indigenous.

Generate direct revenue for the conservation and management of natural resources and protected areas.

Emphasis on the social and environmental Baseline studies and long-term control plan. 
Attempt to maximize economic benefits for the host country, local businesses and the local community, especially those who live in nature and protected areas.

Ensure that tourism development of social and environmental constraints researchers accepted that they have come to be violations.

Emphasis on the environment is designed according to the structural.

Minimize the use of fossil fuels, and protecting wildlife and vegetation of the area with a mixture of natural and cultural environment (Goeldner, 2000).

\section{Sustainable Ecotourism}

The ecology of sustainable ecotourism in the point of ecotourism means respond to current needs of ecologists and pay to maintain and develop ecotourism opportunities for the future instead of damage the ecology try in order to maintain stability. This is called sustainable ecotourism.

In sustainable ecotourism the main motivation of travel to nature is visit for natural attractions concludes physical features and native culture of an area's and ecotourism after observation he leaves that area without harm or destroy on them.

Thus, while recognizing the cultural, historical and natural aspects of the area, maintain the dignity and status of the ecosystem and creating economic opportunities and income for local people.

In sustainable ecotourism to maintain strong support of attractions and natural beauty should be provide required credit and financial resources. So, we can say that sustainable ecotourism is an anti- thesis for tourists who only thinks short-term interests (Goeldner, 2000). In a sustainable ecotourism is discussed a longterm interests of continuity and in this regard; Ecotourism is one of valid experience through physical and mental challenges, and to bear present difficulties and discomfort of travel for the experience and knowledge.

A sustainable ecotourism is a management approach that due to value target, economic, social and environmental with cooperation of authorities and community people through appropriate legislation and regulations and applying them affecting the preservation lead to maintain of nature directly and indirectly to achieve sustainability in ecotourism engaging local populations in ecotourism management and conservation of natural resources and cultural resources is inevitable, in consideration of ecotourism should be applied attention to environmental standards; this should not be considered only in protected areas but in planning all activities and programs of management and development should also be considered.

Finally, successful realizing of ecotourism depends to the sustainable development of ecotourism in sub-groups that includes exchange rates, transportation systems, peace and security, telecommunications systems.

\section{Community-Based Ecotourism}

A community-based ecotourism is a phenomenon in progress throughout the developed world. This concept indicates that community has a critical control and involvement in the project of ecotourism and revealed that the majority of the benefits of ecotourism will remain in community. Three major types of community-based ecotourism is known. Pure simplest model suggests that community is owner and manager of capital. All members of society as a drive system used in the project and its benefits to the project is related to their accounts. The second type consists of community- 
based ecotourism and the group families in the community. The third type is a collaborative effort between the community, family, and foreign business associates.

The relationship between indigenous communities and tourism is very elegant. Tourism economy often consume a large share of local resources and low economic benefits to the host community. Involvement of local people is presented as a part of the tourist attractions in ecotourism in terms of representation and manifestation culture which this problem continues to today and it gives to local people a sense of distrust to developing the tourism in general and weaker reason to believe the potential for eco-tourism. They are often seen as local control over their territories and the future of their community, and unfortunately, their concerns may be manifested in various combinations. Some major concerns of indigenous people include:

Need to tools to look at the agreement

The importance of reviewing and informed consent

Criteria for determining the need for cultural diversity in the field of biodiversity

Establish a process for making complaints, and investigating the involvement of local Develop a deeper evaluation of indigenous rights isolated rural communities and of others.

\section{World Experience}

Including ecotourism centers in the world characteristics can be mentioned the following:

Tourist resorts of the Walt Disney, Tourist Village, Village tourism, Green Pia (Green pia), village tourism - Fort Kalyz entertainment.

\section{Vernacular Architecture}

The subject of vernacular architecture has been seriously considered by those interested in this interest and it $t$ has continued from 18th century ever since. During this time, 1960 is of particular importance. In this era, vernacular architecture studies was aimed to a new approach and continued. Until 1960, most studies were considered on indigenous architecture based on individual interests and goals are few enthusiasts.

But after the year 1960, resulting in the growth of modern architectural appearance emerges shortcomings and swirl degree of uncertainty with respect to this type of architecture. This attitude will emerge not only in western countries but also in developing countries and the subsequent Islamic countries. In 1964, Bernard Rudofsky provided an exhibition entitled "Architecture without Architects "(provided with the book of the same name. According to some, this incident began as a turning point in the West's attention of architecture and the beginning of many researches in the field. Wodehouse has been mentioned in the introduction to his book fairly accurate description of searches and studies on the subject before and after the local architecture since 1960.

The rapid growth of industrialization and modernization of their societies, problems, and shortcomings of these changes were revealed one after another, and cause prompting authorities to think. This applies to all fields including architecture occurred in the community. Including solutions for improving the condition of architecture was devised attention back to the pre-modern architecture and its positive aspects of learning and applying again the values and principles. So after 1960, vernacular architecture was watching as a source to find solutions to overcome some 
shortcomings and deficiencies and problems of modern architecture in different parts of the world. Thus, this study not only to spend time understanding the local architecture, but also in order to find solutions for continuity of its positive characteristics was followed up. The motive and purpose of indigenous architectural studies and assessment of its character, trying to find ways to transfer or re- create useful logical principles of governing it.

\section{Disposition of Vernacular Architecture in Iran}

Iran, like many other Islamic countries, has been witnessed fundamental changes to the system or the traditional to the modern and contemporary Western system. The changes occurred since the beginning of the twentieth century and continued until the 1979 Iranian Revolution. After the Islamic revolution, the process of modernization and Westernism which was doing in all cultural, social, economic, political and etc., stopped, and a reversed process began into Iranian and Islamic architecture. This approach has found in all fields of society, including in the realm of architecture (Vaziritabar, 1990). Spin of Iranian population from Iranian and Islamic values to modern values of the West of "modernizing Iran" and by Banan (Banani) is described in detail (Banani, 1961). He describes how various aspects of the country such as the economy, education, judiciary and judicial system, the military and administrative structure has changed from traditional methods to the Western model. With the advent of the new vision of architecture, process and follow -up of the world architectural style (International Style) was questioned. This design method that fully coordinate with Westernism process the country in the period before the revolution do not seem to fit very logical in society. Therefore, from the perspective of the experts, solution was to look into the past, where the cessation of spontaneous and indigenous architecture occurred

They believed that the precision to Iranian original architectural before modern society and western of Iran, we can find new ideas and improve ways and promotion of it in link with the architecture of time governed. By result of this new attitude increased again attention to the Iranian traditional architecture and native. It was located also the subject of study and professional practice some of architects and architecture critics and the architecture school .Many researchers have tried to research on traditional architecture in Iran (Sanei et al., 1369). They pay particular attention to all of Iran's traditional and Islamic architecture and the fundamental changes occurring in the departments of education stated after the revolution and they have noted that several courses in this regard, for example , new educational programs are predicted.

\section{The Study of Hormoz Island as the Study Scope}

Position of Iran among the first five countries to take advantage of the most diverse regions in the world means that in regard to any investment, especially in tourist ' investment provide pole ecotourism rely on the resources of the country, it's so accessible they often do not even need the double attraction absent regardless of issues such as cultural tourism market constraints and lack of social development of leisure tourism, ecotourism potential of the point much more than other parts of the tourism .

Broad set of distributed resources, unregistered and in many cases stall, there's a form of ecotourism, it is obvious 
that, due to the diversity of topographic and geomorphologic natural resources is immense.

Hormozgan province is located in southern Iran and between geographical coordinates 25 degrees and 30 minutes to 28 degrees and 53 minutes of north latitude and 52 degrees and 44 minutes to 59 degrees and 16 minutes east of the prime meridian in an area. Its square is about 71,000 kilometers, its south of it surround warm waters of the Persian Gulf and Oman Sea, approximately 900 kilometers. Island of Hormoz is limited on the North West to Bandar Abbas and on South- East to the island of Qeshm and Lark. The island is oval shaped which small diameter is $5 / 5$, large diameter is between $7 / 5$ to $9 \mathrm{~km}$ and its area is about $45 \mathrm{~km}$ and $14 \mathrm{~km}^{2}$ of it contains vast deposits of alluvial and a range of 31 square kilometers, including the various layers of Hormoz. The highest point on the island at a height is 228 meters and belowest the lowest point of the curve is zero. So the average altitude is 114 meters on the island of Hormoz.

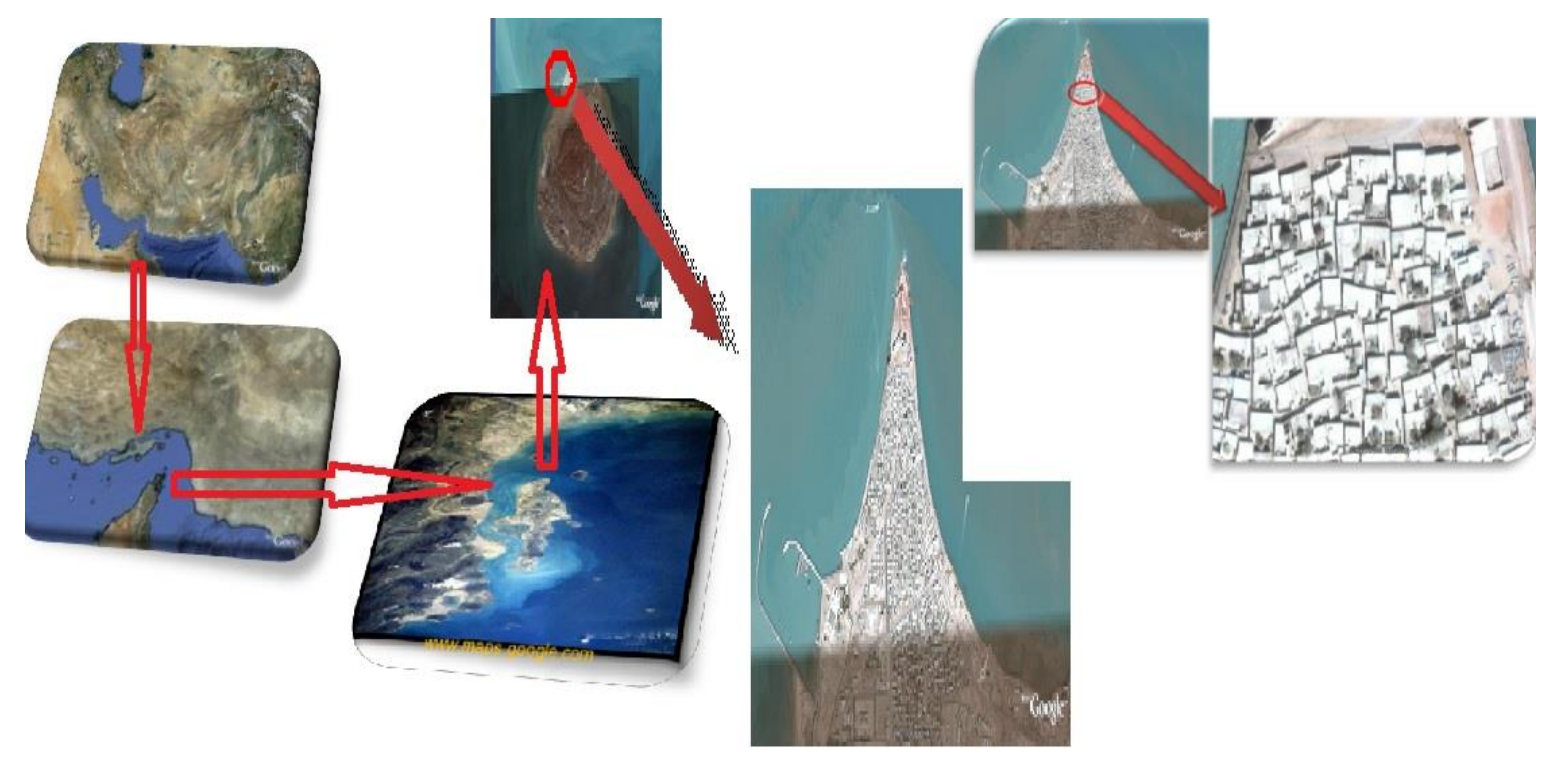

Figure 6. The Position of Hormoz Island in Iran and Old Context

\section{The Old Context}

This context which involved formation initial core of the city has an old large ancient and it is mainly encompasses by old materials and formed by old and the little pieces. Among of characteristics of the tissue can be indicate to $100 \%$ residential tight and narrow and meander the streets and also, the compression and tension in the tissues mentioned roadway access problem and needs to repair buildings is features of this organ.
This context that dates back nearly three decades with different materials and with relatively wider access that enables it to cross the roadway formed. Existing of users such as user training, religious and business has led to a greater diversity of context and also, tangled and compacted of old context have been seen in less . Access is relatively direct but the context has no good a space link.

\section{Intermediate Context}




\section{New Texture}

The oldness of new context is a decade and less than of it and in fact, in order to meet needs of the young population of the city is formed. One of the features of this context

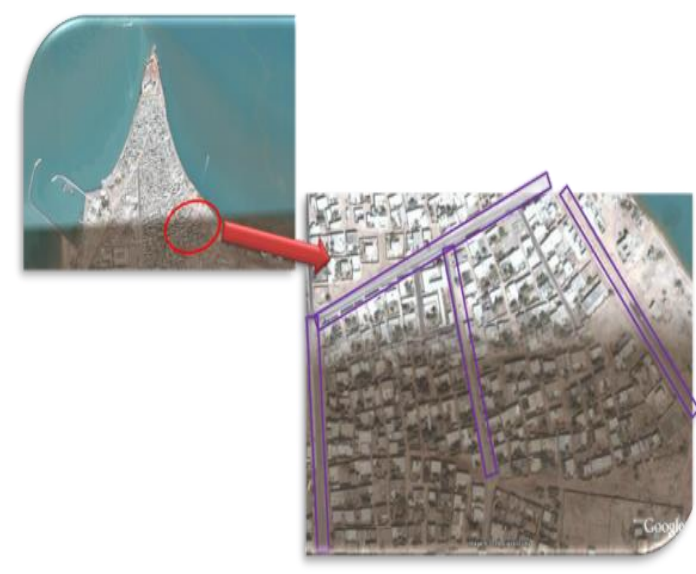

Figure 8. New Structure of Hormoz

\section{Social- Cultural Benefits Ecotourism on Island of Hormoz}

Wisely planning and institutionalize of sustainable development on island of Hormoz, the considerations social and cultural is inevitable. The island for sake of its traditional context, local culture, context-specific architecture and pristine landscapes traditionally is very important According to a comprehensive plan for the city of Hormoz and determination the dominant economy based on tourism industry and tourism in point of view of cultural are dealt with to assess the benefits and harms.

If benefits of tourism Economic divided well into the area, then living standards will be promote and to help the improvement of services and facilities financially.

The possibility of cultural exchange between locals and tourists, which makes the exchange of cultures and learn from each other and respect towards it.

Feeling local people from praise and honor of tourists towards their culture. can be indicate the application of durable materials such as concrete, iron and having the access hierarchy which be able to meet the needs of today. Main new user is located in this context.

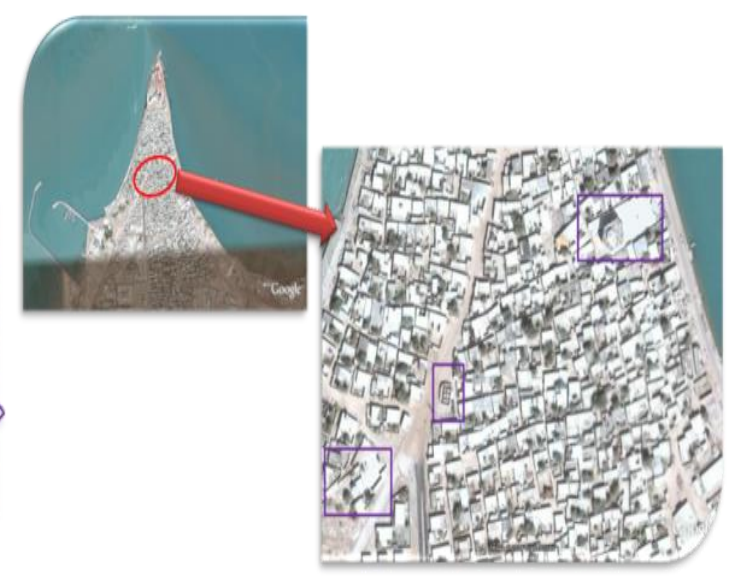

Maintain customs and traditions, traditional context island, games and local events.

Enhancing welfare.

Preserve and protect traditional landscapes and ancient monuments.

Revive old customs, local language, local markets, local customs, arts and crafts, dance, and music.

Local communities are involved in tourism affairs.

Protection of cultural heritage, history, arts and crafts area.

Strengthen and support local services such as public transportation and health care.

Establishment of facilities and new attractions such as cultural facilities, entertainment centers and etc.

Creation of more awareness in the field of terms of local cultures, professions and cultural identity.

Development of tourism on the island has led to the increasing role of women.

Historical and archaeological sites due to neglect and lack of funds for repairs and maintenance are to be destroyed. By development of tourism is expected to 
prevent the destruction of historical and budgeted cost to repair it.

\section{Analysis of Findings Based SWOT}

SWOT is synonyms terms: strengths (Strenghths), weaknesses, opportunities and threats. The first step in planning process is to etermine the vision and mission of organization, then through SWOT analysis which is one of strategies develop tools and we can designed it to organization which is commensurate with its environment. Using from this analysis it is possible to obtain firstly, to analyze the environment foreign and domestic, and secondly strategic decisions adopted which the strengths of the organization with the opportunity to make a balanced environment.

Due to lack of services and facilities in one area related to tourism, it can be a problematic subject. For Hormoz Island with power and numerous attractions for development of tourism industry, it can be very helpful. But getting the benefits and appropriateness, which is possible when its appropriate and social infrastructure, is provided, too. Also, before any planning and implementing designed programs, having the statistic and information of the characteristic of tourists is an inevitable subject; therefore, in first step, recognition of attractions and planning for development of them in next steps is a necessity affair (Behzadfar and Zamanian, 1386).

At the same time to achieve the best strategies in the tourism sector in cooperative research, information technology, product development, human resources, marketing and supervision is necessary for law enforcement (Shahande , 1387) in other words, considering the tremendous impact of tourism in the field of economic, social and cultural societies in today community, we must be try for a managerial view and wisely management about tourism with proper planning (Mahallati , 1380).

\section{Weaknesses, Strengths, Opportunities and Threats of the Studied Area According to SWOT Analysis}

To achieve the proper strategies, first of all, we must be paid to the analysis of the internal and external environment. In this section reviews the opportunities and threats of the external environment and internal environment with examines the strengths and weaknesses.

\section{Weaknesses}

Lack of local recreational

Construction of tune with the shape of earth

Construction without permits and coordination with the municipal council inside of and organs, institutes and in land area

Turbulence in density regulations and unnoticed topography and natural features Perform construction non-coordinated with the shape of land and loss of natural identity

Lack of public arenas for conflict and social movements

Weakness of legibility and identity in new development.

\section{The Strengths}

Absence of symptoms and normal or artificial site

The slight slope towards the sea

Existence of a street30 meters in the south of the site

There is no noise on the site

Clear air and peace and quiet on the site Most of the site's proximity proximity to nature (in the North of Sea, the southern mountains and pristine natural spaces) 
The natural environment of rivers, hills, mountains

There is an open ground in the area of undisturbed natural lands

Ability to develop key tourism and recreation in the area

Ability to highlight the range of topographic conditions causing visual symptoms and indicators of bone boundaries.

\section{Opportunities}

The possibility of taking advantage of the winds of region suitable

Possibility of building protection against the along wind

Ability to improve people's lives and improve the services and facilities of the complex operation of ecotourism

The possibility of cultural exchange between locals and tourists

Preserve and protect the historic landscape and ancient traditional

Revive old customs, local language, local markets, local customs, arts and crafts, dance and music.

Engaging island local communities in tourism affairs

Strengthen and support local services such as public transport and health care Creation of new features and attractions such as cultural facilities, recreation centers, etc.

Creatation more awareness in terms of local culture, professional and cultural identity

Cost of allocating funds for the restoration of monuments

Limit vehicles on the island of Hormoz

Natural of islands and the ability to load ecotourism activities associated with the ancient history of the island.

\section{Threats}

There is a valuable monuments on the island
Lack of adequate water resources in the region

Endanger the cultural and historical resources of the community frequently visited tourist

Neglect and lack of sufficient funds for the restoration and preservation of historical sites and ancient

Increasing population density and island Conflict between traditional values cultural tourism culture

\section{Discussion and Interpretation of Results and Exploitation Strategies}

Four strategies as follows for planning of SWOT matrix elements in order to analysis all strategic factors (opportunities, threats, strengths and weaknesses) in ecotourism industry development on the island of Hormoz was observed.

\section{Competitive Strategies / Ofensive SO}

This strategy indicates the state optimum position and moving out of per position in SWOT matrix to ideal situation that it use by relying on the power of all the positive points advantage and competence to maximize opportunities, demands and opportunities

Enhancing and increasing of presentation facilities in tourism resources with national and international importance.

Development of recreational facilities through the development of ecotourism as appropriate and complementary tourism attractions for tourists, especially foreign tourists increased duration.

Planning to increase of attract tourists from Arab countries which result to increase investments in other areas

Planning for development of handicrafts and other related businesses, to create jobs and sustainable income.

To limits for entering the tourists to country, especially in field of Visa and 
religious issues and increasing social benefits for foreign tourists.

Use of manpower skilled and experienced in order to creation of cooperative association and as well as promoting and educating people tourism through various meetings with people of the island of Hormoz.

Creation of coordination between different institutions and related sectors to integration tourism ecotourism ' functions, by integrating the functions of organizing meetings and coordinating the implementation of management measures with the participation of governmental organizations, NGOs, citizens and entrepreneurs.

Supporting the preparation and operation of the private sector to invest in tourism industry on the island of Hormoz, through the transparency of local government policies and programs, and how the tax subsidy and bank loan and extra.

The main focus of tourist activities on the utilization of existing resources without the use of tourism as perspectives, elevations, and monuments and....in order to earn money and create jobs and develop the island.

Creation of spaces and specific activities to enable appropriate interaction and social interaction.

Creation of vitality, joy and fun in public spaces via ecotourism

Perception of sequential elements and symbols in order to help the readability of their relationship with each other ecologically oriented architecture.

Increase readability and visibility within the urban routes and landmarks using the canvas element oriented architecture.

\section{Diversification Strategies Based on ST}

The aim of this strategy, taking maximum advantage of the strengths and advantages in part to deal with bottlenecks, threats and harmful external (environmental) and to minimize them.

Increasing funding for the development of tourism attractions and creating management transparency for executive and realization of the development of tourism and ecotourism

Increase awareness in advertising and the media about the benefits of tourism activities in the region and eliminate the adverse effects

Enhancing the physical fabric of the city and increasing the visual quality of the environment and ecotourism attractions

Diversifying to facilities, activities and tourist services in order to satisfy tourists and therefore increasing the number of tourists on the island of Hormoz and the use of different categories of people in a variety of activities

Ability and determination of optimal density of population at different tourist locations on the Island of Hormoz in order to reduce the pressure and density over the places and attractions and to prevent the loss and degradation

\section{WO Strategies Based Review}

This strategy aims to reduce and minimize the weaknesses and vulnerable aspects in order to maximize opportunities, demands situations.

Strengthen interisland transport, outward and increase transportation service to the tourism destinations.

Attempt to identify and record tourist attractions in the National Heritage List and the world for the better understanding and knowledge of ecotourism attractions and tourism centers according to regional powers

Increased coordination related to tourism and development organizations to implement best management and development programs of tourism 
Separation of Islamic culture and cultural tourism in the country, leading to limited of tourism in country and destroys other types of tourism.

Review and development of related institutions and organizations in studied region to educate the public and tourists in research in order to gain a better and more targeted benefits and positive effects of tourism.

\section{Defensive Strategies Based on the WT}

The objective of these strategies, minimizing the risk of weaknesses, and external threats and problems. In this case, the most worrisome strategic situation is dire need to re-evaluate, revise and strengthen the structure, function, and strategic policy objectives there.

To provide a healthy figure out the correct mentality in the minds of the citizens' participation in the international (NGO) formed by NGOs.

Dealing with urban affairs and prevent insecurity and disorder and crime in the city, especially in older neighborhoods.

Competent and efficient management practices in tourism planning to increase investment in the tourism context.

Repair restored historical monuments and natural and human hazards.

Training and giving information to people on how to deal with tourists and tourism, in order to prevent the conflict between tourists and people, it means local people should be respect to tourists in field of culture and customs, and other special places.

Develop specific rules for optimal utilization of tourism attractions and products and to prevent the destruction, pollution and loss of resources in these areas.

Preparing and encouraging people to participate in the development of infrastructure, tourist facilities and earn money this

Way, and also the participation of the private sector in areas where

People cannot participate or investment. In order to encourage people to travel to the island of Hormoz and Ecotourism Tourism Development in this island, the necessity of doing research in the field of tourism and marketing research aspects various different attractions should be promoted and utilized.

\section{Result}

Tourism as one of the most important factors areas ' development is an exchange and balanced activity which lead to social and economic development in regional level and justify distribution of income and also, it contributing the employment and today, its related activities included the largest industrial sector and world exports. In the process of acquiring the tourists to nature which is arising from the presence of artificial life, growing enthusiasm for new discovery and understanding of a range of values, activities and cultural exchanges of the concept is interesting and valuable, as is depicted in tourism, the increasing inclination towards understanding is a natural unit and monuments and cultural heritage communities, the value of which may even local residents will be deprived of it.

The impact of tourism on the island Hormoz has both positive and negative effects. The effects of the amount and intensity by a set of factors such as the development of tourist destinations, flexibility, patterns and levels of development and size of facilities is determined. Significant effects on the environment and culture, developing countries almost had a result attract 
tourists which is much higher than in developed countries. Many of the countries are small islands that rely on natural resources, climate and landscape to attractive or tourist destination. Activities are concentrated in coastal areas and may cause changes in the natural environment. Also it should be said that tourism industry is often one of the major producers of foreign currency in these small countries.

So no wonder that the country's government to promote the camp and tourist facilities and air and sea units have tried to increase tourism to islands. "Capacity or otherwise unacceptable levels" are concepts that analyzed the effects of tourism on the environment and society. No "threshold capacity measure" is not useful for all countries or some countries. While no general definition of the capacity of society to include all topics that do not exist. There is a knowledge. Some certain degree of acceptable are a change in the dependent subsystems, such as economic, social and environmental. Intensity of tourists or terms of the number of imported tourists per square kilometer is indicator of tourist pressure in the physical environment.

Ecotourism in Iran as one of the five countries has the most diverse regions in the world (one of ten country's cultural and historical) and one of the most diverse biosphere reserves ground has more than advantage other branches tourism. Cultural and historical tourism, with the ever more dominant role in Iran's tourism industry has many advantages and is irreplaceable, but the market is more limited than in other branches of the tourism industry .Nothing makes a more general audience. Ecotourism development requires massive investment for infrastructure facilities has no need to facilities like hotels and road. Ecotourism need to human sources concern to ecotourism facilities and accommodations therefore may not require heavy investment. While on the other hand it can cause massive volume of more job opportunities, benefits directly to the poor and indigenous people noticed. According to what was said Hormoz Island tourism development, with providing new employment opportunities for local people is an instrument for again vital and it causes the development of the area. On the other hand, Hormoz island tourism development without proper planning framework prepares for irreparable damage and loss. Therefore, according to the ability and the environmental characteristics should be utilize specific type or combination of approaches and strategies especially strategic planning for tourism development of the island of Hormoz.

\section{References}

Alvani, S.M. and Piruzdokht, M. (2006). Tourism management process Cultural Studying Edition, No. 1. Tehran. Iran.

Saneie, H., (1990). What happened to the traditional architecture of Iran? Building magezine, No. 16, Tehran.

Shahandeh, B. (2007). Environmental management systems and Sustainable development in Qeshm Free Zone, M.Sc. Thesis. Tehran University.

Zahedi, S. (2002). Challenges of sustainable development from ecotourism perspective, Modares magezine, Tarbiat Modarres University Press, Volume 7, Number 3, Tehran.

Zahedi, S. (2002). The principles of sustainable tourism and ecotourism, Allameh Tabatabai University Press, First Edition. 
Ranjbariyan, B. and Zahedi, M. (2000). Tourism planning at national and regional level, University of jihad publication First Edition.

Mahallati, S. (2001). An Introduction to the tourism, Shahid Beheshti University Press, First Edition.

Behzadfar, M. and Zamaniayn, R. (2006). The use of multi-criteria decision-analytic hierarchy process in tourism planning case study: city of Nishapur, International Journal of Engineering Science, Iran University of Science and Technology, No. 5, winter: 121.

Ackoff, R.L. and Pourdehnad, J. (2000). On misdirected systems, "Systems Research and Behavioral Science" John Wil ESCAP, (2003) Ecotourism development in the pacific Islands, "ESCAP Tourism Review", No.23, United Nations, New York ey \& Sons, USA.

Godfrey-Smith, W. (1979). The value of Wilderness: environmental ethics", Vol.1. Goeldner, R, et al. (2000). Tourism, Principales, Practices, Philosophies", John Willey \& Sons Inc., New York.

How to cite this article: HasanAli Pourmand, HamidReza Ameri Siahouei, Mohammadreza Yeganeh, Evaluation the Effect of Construction of Ecotourism Entertainment Facility in Hormoz Island with the Vernacular Architecture Approach. International Journal of Advanced Studies in Humanities and Social Science, 2019, 8(1), 28-44. http://www.ijashssjournal.com/article 84107.html
Goeldner, R, et al. (2000). Tourism, Principales, Practices, Philosophies", John Willey \& Sons Inc., New York.

Tisdell, C.A. \& Wilson, C. (2000). A Study of the Impact of Ecotourism on Environmental Education and Conservation: The case of Turtle Watching at an Australian Site, Economics, Ecology and Environment Working Papers 48365, University of Queensland, School of Economics.

Laarman, J.G. and Durst, P.B. (1987). Nature travel in the tropics: Is this growing enterprise a trend in wildlands management? Journal of Forestry, 85, 43-46.

Bernard R. (1964). Architecture without Architects, a Short Introduction to Nonpedigreed Architecture.

Vaziritabar, S. (1990). Design and Privacy in Modern and Traditional Housing In Iran, Ph.D. Thesis,Oxford, UK.

Banani, A. (1961). The Modernization of Iran, 1921-1941, (Hardcover). 